\title{
SISTEM PENDUKUNG KEPUTUSAN PRIORITAS CALON PENERIMA PROGRAM INDONESIA PINTAR PADA SISWA SEKOLAH MENENGAH PERTAMA MENGGUNAKAN METODE TOPSIS
}

\author{
Deddy Kusbianto P. ${ }^{1}$, Elok Nur Hamdana ${ }^{2}$, Dimas Dwiki Fahreza ${ }^{3}$ \\ ${ }^{1,2}$ Program Studi Teknik Informatika, Jurusan Teknologi Informasi, ${ }^{3}$ Politeknik Negeri Malang. \\ 1'deddykusbianto@gmail.com, ${ }^{2}$ elokhamdana@gmail.com, ${ }^{3}$ dwikifahreza@gmail.com
}

\begin{abstract}
Abstrak
Pendidikan merupakan hal penting dalam memajukan pembangunan negara, dengan itu pemerintah membuat kebijakan wajib belajar pendidikan sembilan tahun. Namun perekonomian masyarakat yang minim sering kali mengakibatkan mereka lebih memilih bekerja sebelum menuntaskan pendidikan dasar sembilan tahun tersebut. Demi mewujudkan hal tersebut pemerintah memiliki program bantuan pendidikan PIP (Program Indonesia Pintar) yang ditujukan pada masyarakat miskin. Namun implementasinya masih terdapat banyak kendala yang mengakibatkan tidak tepat sasaran dalam pemberian program bantuan pendidikan tersebut.

Oleh Karena itu, untuk mengatasi permasalahan tersebut perlu adanya sistem dalam menentukan prioritas calon penerima PIP dengan menambahkan beberapa kriteria yang lebih mendasar. Pada penelitian ini dirancang sistem pendukung keputusan menggunakan metode TOPSIS (Technique for Order Performance by Similarity to Ideal Solutions) dengan beberapa kriteria yaitu Status Aktif Siswa, Surat Keterangan Miskin, Kondisi Yatim Piatu, Gaji Orang Tua, Presentasi Absensi. Pada aplikasi ini didapatkan hasil akhir berupa perankingan prioritas siswa yang akan menerima bantuan PIP.
\end{abstract}

Kata kunci: Sistem Pendukung Keputusan, penerima bantuan, Indonesia Pintar, Topsis.

\section{Pendahuluan}

\subsection{Latar Belakang}

Pada akhir tahun 2014 pemerintah membuat Program Indonesia Pintar (PIP) yang menjadi bagian penyempurnaan Bantuan Siswa Miskin. PIP merupakan bantuan dari pemerintah untuk masyarakat miskin dalam hal pendidikan yang diberikan kepada keluarga dengan anak usia sekolah (6-21 tahun) berasal dari keluarga miskin. Pihak sekolah berkewajiban untuk mendaftarkan siswanya yang mempunyai KIP, KKS ke Dapodik supaya bisa segera mendapat manfaat PIP. Sekolah tetap bisa mendaftarkan siswa miskin yang tidak memiliki Kartu Indonesia Pintar ke Dapodik dengan mendata siswa yang memiliki KPS, PKH atau SKTM dan sesuai dengan kriteria penerima PIP agar siswanya segera mendapat bantuan tunai PIP. Kendala yang dihadapi oleh pihak sekolah adalah terdapat banyak kriteria yang harus diperhitungkan sehingga kesulitan dalam menentukan prioritas calon penerima PIP.

Berdasarkan permasalahan tersebut maka dapat diambil kesimpulan bahwa banyaknya kriteria bagi siswa miskin yang tidak memiliki KIP, menyulitkan pihak sekolah dalam menentukan prioritas siswa miskin yang ingin didaftarkan sebagai penerima PIP. Oleh karena itu, pada penelitian ini dibuat sebuah aplikasi untuk membantu pihak sekolah dalam menentukan prioritas calon penerima PIP menggunakan metode TOPSIS untuk menentukan urutan calon penerima PIP.

\subsection{Rumusan Masalah}

Berdasarkan latar belakang yang telah dikemukakan, maka rumusan masalah yang diangkat dalam penelitian ini adalah bagaimana cara menentukan prioritas calon penerima PIP menggunakan metode TOPSIS?

\subsection{Batasan Masalah}

1. Objek penelitian berada di SPMK St. Yoseph Kepanjen.

2. Sistem menggunakan data siswa kelas VII tahun 2017 pada SMPK St. Yoseph Kepanjen. 


\section{Landasan Teori}

\subsection{Program Indonesia Pintar}

Program Indonesia Pintar adalah salah satu program nasional yang bertujuan untuk meningkatkan angka pertisipasi pendidikan dasar dan menengah, meningkatkan angka berkelanjutan pendidikan, menurunkan kesenjangan partisipasi pendidikan, meningkatkan kesiapan siswa pendidikan menengah untuk menghadapi pasar kerja. Program Indonesia Pintar diselenggarakan oleh Kementrian Pendidikan dan Kebudayaan dan Kementrian Agama. Program Indonesia Pintar merupakan penyempurnaan dari program Bantuan Siswa Miskin (BSM) yang memberikan bantuan tunai pendidikan bagi anak usia sekolah yang berhak terutama dari keluarga pemegang KKS dan ditandai dengan Kartu Indonesia Pintar (KIP) TNP2K (2016). Selain KKS dan KIP, pihak sekolah juga bisa mendaftarkan siswanya yang kurang mampu dengan meminta keluarga siswa membawa surat keterangan PKH, KIS atau SKTM. SKTM adalah surat keterangan tidak mampu yang ditujukan untuk keluarga miskin dan bisa didapat melalui kelurahan setempat Pemerintah Kabupaten Bangil (2016). KKS atau Kartu Keluarga Sejahterah adalah bantuan non tunai melalui pembukaan rekening simpanan bagi rakyat kurang mampu Azarine (2016). PKH adalah Program Keluarga Sejahterah yang merupakan bantuan non tunai bagi Rumah Tangga Sangat Miskin (RTSM) yang akan menerima bantuan jika keluarga tersebut menyekolahkan anaknya dengan tingkat kehadiran tertentu Kementerian Sosial (2016). KPS adalah Kartu Perlindungan Sosial yang merupakan kartu untuk mendapatkan manfaat dari Program Subsidi Beras, Bantuan Siswa Miskin dan Bantuan Langsung Sementara Masyarakat TNP2K (2016). KIS atau Kartu Indonesia Sehat adalah penanda masyarakat miskin agar mendapatkan pelayanan kesehatan melalui Jaminan Kesehatan Nasional TNP2K (2016).

\subsection{Kartu Indonesia Pintar}

Kartu Indonesia Pintar (KIP) diberikan sebagai penanda dan digunakan untuk menjamin serta memastikan seluruh anak usia sekolah dari keluarga pemegang KKS untuk mendapatkan manfaat dari PIP bila terdaftar di sekolah, madrasah, pondok pesantren, kelompok belajar atau lembaga pelatihan. KIP juga mencakup anak usia sekolah yang tidak berada di sekolah seperti Penyandang Masalah Kesejahteraan Sosial (PMKS) seperti anak-anak di panti sosial, anak jalanan, pekerja anak dan difabel TNP2K (2016).

\subsection{Sistem Pendukung Keputusan}

Sistem Pendukung Keputusan adalah sebuah sistem yang mampu memberikan kemampuan pemecahan masalah maupun kemampuan pengkomunikasian untuk masalah dengan kondisi semi terstruktur dan tak terstruktur. SPK bertujuan untuk menyediakan informasi, membimbing, memberikan prediksi serta mengarahkan kepada pengguna informasi agar dapat melakukan pengambilan keputusan dengan lebih baik. Secara umum sistem pendukung keputusan dibangun oleh tiga komponen yaitu database, model base dan user interface Riadi (2013).

\subsection{Metode TOPSIS}

TOPSIS (Technique For Others References by Similarity to Ideal Solution) adalah suatu metode pengambilan keputusan yang memiliki solusi ideal positif dan solusi ideal negatif. Solusi ideal positif didefinisikan sebagai jumlah dari seluruh nilai terbaik yang dapat dicapai untuk setiap atribut, sedangkan solusi ideal negatif adalahseluruh nilai terburuk yang dapat dicapai untuk setiap atribut Zlatko \& Vedran (2013).
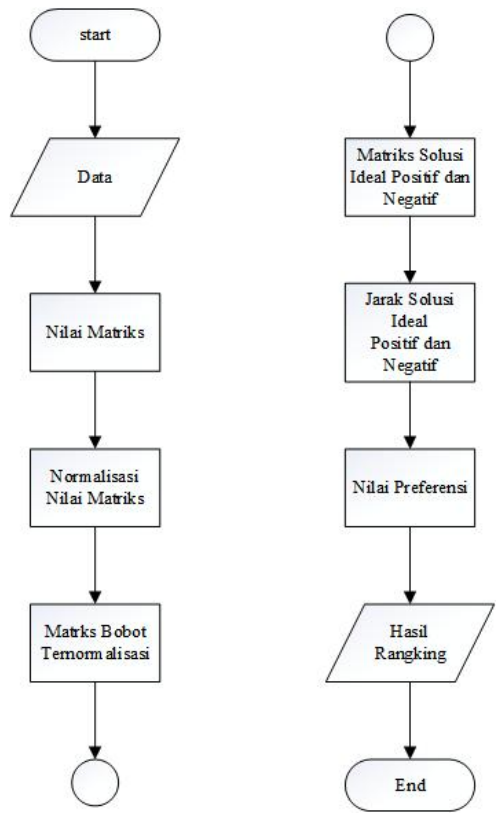

Gambar 1. Flowchart TOPSIS

Langkah-langkah pada metode TOPSIS adalah

a. Membangun matriks keputusan.

b. Membangun normalisasi matriks keputusan.

c. Membuat matriks bobot ternormalisasi.

d. Menentukan matriks solusi ideal positif dan solusi ideal negatif.

e. Menghitung jarak solusi ideal positif dan solusi ideal negatif

f. Menghitung nilai preferensi 
g. Merangking nilai preferensi. Dengan mengurutkan nilai preferensi masing-masing siswa dari nilai tertinggi ke nilai terendah.

\subsection{Apache Server}

Apache Server merupakan web server open source yang mampu melayani koneksi transfer data dalam protocol HTTP. Web server merupakan hal penting dari server diinternet, hail ini disebabkan karena web server dirancang untuk melayani berbagai macam jenis data dari text hingga grafis. Selain open source, web server Apache juga fleksible terhadap berbagai sistem operasi seperti Linux, Windows 9x/NT/2000/XP maupun Vista Riadi (2013).

\subsection{XAMPP}

XAMPP adalah sebuah software yang berfungsi untuk menjalankan website berbasis PHP dan menggunakan pengolah data MYSQL di komputer lokal. XAMPP berperan sebagai server web pada komputer lokal. XAMPP juga dapat disebut sebuah Cpanel server virtual, yang dapat membantu melakukan preview sehingga dapat dimodifikasi website tanpa harus online atau terakses dengan internet Dudung (2016).

\subsection{PHP}

PHP adalah bahasa server side scripting yang menyatu dengan HTML untuk membuat halaman web yang dinamis. Karena PHP merupakan server-side-scripting maka sintaks dan perintahperintah PHP akan diesksekusi diserver kemudian hasilnya akan dikirimkan ke browser dengan format HTML.

Salah satu keunggulan yang dimiliki PHP adalah kemampuannya untuk melakukan koneksi ke berbagai macam software sistem manajemen basis data atau Database Management Sistem (DBMS), sehingga dapat menciptakan suatu halaman web dinamis. PHP mempunyai koneksitas yang baik dengan beberapa DBMS seperti Oracle, Sybase, mSQL, MySQL, Microsoft SQL Server, Solid, PostgreSQL, Adabas, FilePro, Velocis, dBase, Unix dbm, dan tidak terkecuali semua database ber-interface ODBC Arief (2011).

\subsection{Database MYSQL}

MySQL merupakan sistem manajemen database yang bersifat open source. MySQL mendukung beberapa fitur seperti multithreaded, multi-user dan database manajemen sistem. MySQL dan PHP meurpakan sistem yang saling terintegrasi dalam pembuatan database dengan menggunakan sintak PHP, input yang dimasukkan melalui aplikasi web dapat langsung dimasukkan ke database $M y S Q L$ yang ada di server Widi (2013).

\section{Metodologi}

\subsection{Metode Pengumpulan Data}

Metode pengumpulan data merupakan tahapan yang dilakukan untuk mempermudah dalam pembuatan sistem. Desain penelitian sistem pendukung keputusan prioritas penerima program Indonesia pintar digambarkan pada Gambar 2:

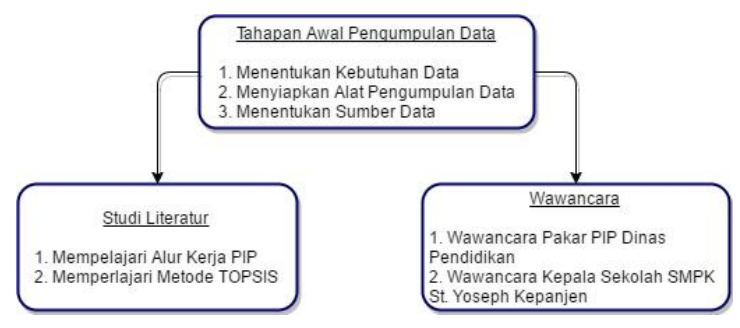

Gambar 2. Tahapan Pengumpulan Data

\subsection{Metode Pembangunan Sistem}

Langkah-langkah dalam membangun sistem pendukung keputusan prioritas calon penerima PIP menggunakan metode waterfall.

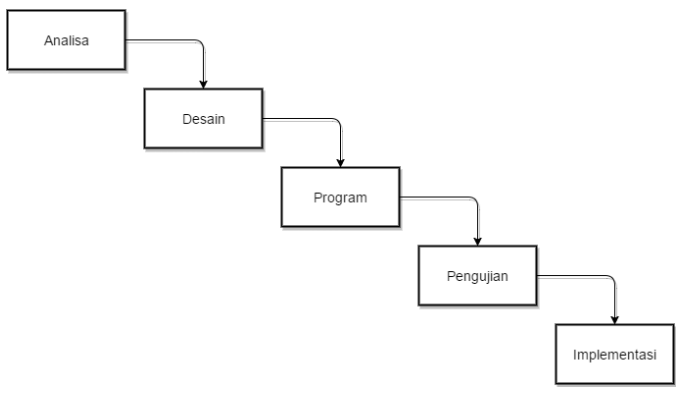

Gambar 3. Metode Waterfall

\subsection{Deskripsi Aplikasi}

Pada sistem berbasis web yang dibangun ini, SPK digunakan untuk membantu pihak sekolah dalam menentukan prioritas siswa calon penerima bantuan sesuai dengan kriteria dan nilai-nilai yang sudah ditetapkan sebelumnya. Sistem ini hanya digunakan oleh pihak sekolah yang terdaftar dalam tabel admin dengan menu beberapa menu, yaitu menu login, menu import, menu lihat data, menu edit data, menu hapus data dan menu proses data.

\section{Analisa dan Perancangan}

\subsection{Analisa Kebutuhan}

Tujuan menganalisa kebutuhan antara lain menganalisa kebutuhan dan keperluan dasar yang akan digunakan dalam pembuatan aplikasi yang diinginkan. Hasil perancangan yang diperoleh adalah pembuatan aplikasi yang dapat digunakan untuk menentukan prioritas calon penerima PIP agar pemberian bantuan tunai PIP lebih tepat 
sasaran. Kriteria yang disarankan oleh bagian KIP dinas pendidikan setelah dilakukan wawancara adalah :

a. Status aktif siswa

b. Jumlah Surat Keterangan Miskin yang dimiliki

c. Kondisi status yatim piatu

d. Gaji orang tua

e. Presentase absensi Siswa

f. Tanggungan pembayaran

g. Indikator lain

\subsection{Desain Sistem}

Pada bagian ini akan diberikan gambaran perancangan sistem pendukung kputusan prioritas calon penerima PIP. Adapun desain sistemnya adalah :

\subsubsection{DFD (Data Flow Diagram)}

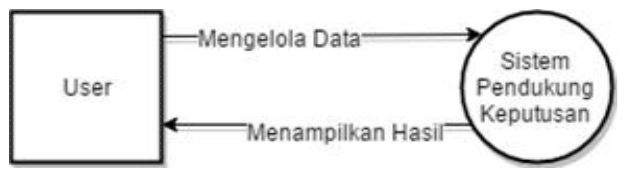

Gambar 4. Diagram Konteks

DFD level 0 atau bisa juga disebut diagram konteks, menjelaskan proses user mengelola data siswa menggunakan sistem, lalu sistem akan menampilkan hasil dari data yang dikelola.

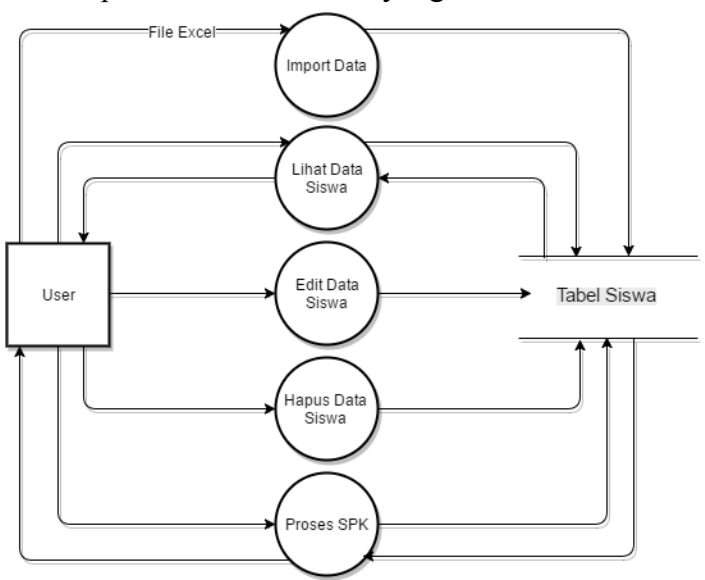

Gambar 5. DFD Level 1

Data Flow Diagram level 1, merupakan gambaran proses yang lebih rinci dari DFD level 0 atau diagram konteks.

\subsection{Perancangan Metode}

Berdasarkan hasil wawancara dengan kepala sekolah SMPK St. Yoseph Kepanjen, maka didapat data seperti pada tabel berikut : a. Skala Nilai

Tabel 1. Skala Nilai

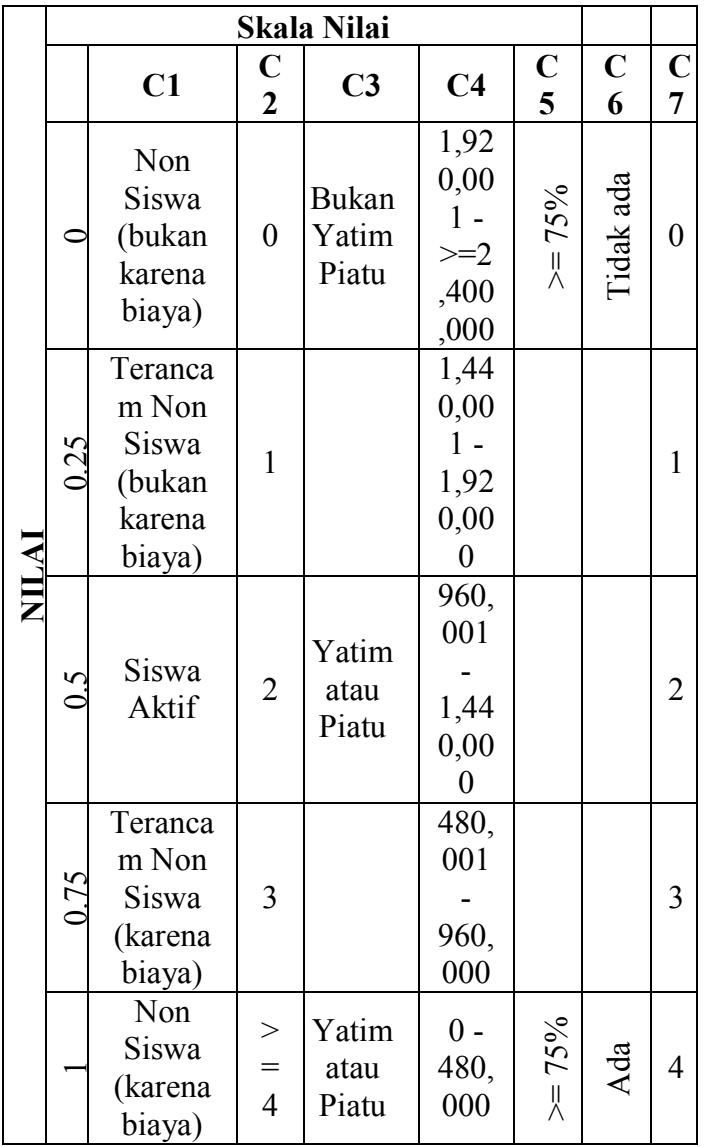

b. Bobot Kriteria

Tabel 2. Kriterian dan Bobot

\begin{tabular}{|l|c|c|c|}
\hline \multicolumn{2}{|c|}{ Kriteria } & \multicolumn{2}{c|}{ Bobot } \\
\cline { 3 - 4 } & Sifat & Nilai \\
\hline C1 & Status Aktif Siswa & Penting & 0,75 \\
\hline C3 & Jumlah SKM & Sangat Penting & 1 \\
\hline C4 & Gaji Orang Tua & Sangat Penting & 1 \\
\hline C5 & Presentasi Absensi & Penting & 0,75 \\
\hline C6 & $\begin{array}{c}\text { Tanggungan } \\
\text { pembayaran }\end{array}$ & Sangat Penting & 1 \\
\hline C7 & Indikator lain & Sangat Penting & 1 \\
\hline
\end{tabular}


c. Data Siswa

Tabel 3. Data Siswa

\begin{tabular}{|c|c|c|c|c|c|c|c|c|}
\hline$\frac{\Omega}{z}$ & 莺 & 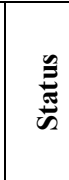 & $\sum$ & $\begin{array}{l}\overline{\bar{n}} \\
\overline{\bar{a}} \\
\underline{\bar{y}}\end{array}$ & : & 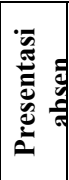 & 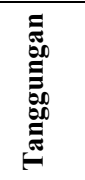 & 駦 \\
\hline 9206 & Aloy & aktif & 0 & $\begin{array}{c}\text { Yatim/ } \\
\text { Piatu }\end{array}$ & $\begin{array}{l}480, \\
001 \\
- \\
960, \\
000\end{array}$ & $\begin{array}{c}>= \\
75 \%\end{array}$ & $\begin{array}{l}\text { Tidak } \\
\text { Ada }\end{array}$ & 0 \\
\hline 9208 & Anto & aktif & 0 & Bukan & $\begin{array}{l}0- \\
480 \\
000\end{array}$ & $\begin{array}{c}>= \\
75 \%\end{array}$ & $\begin{array}{c}\text { Tidak } \\
\text { Ada }\end{array}$ & 0 \\
\hline 9220 & Giga & aktif & 1 & Bukan & $\begin{array}{l}960, \\
001 \\
- \\
1,44 \\
0,00 \\
0\end{array}$ & $\begin{array}{c}>= \\
75 \%\end{array}$ & $\begin{array}{l}\text { Tidak } \\
\text { Ada }\end{array}$ & 1 \\
\hline 9216 & Skola & aktif & 2 & Bukan & $\begin{array}{l}480 \\
001 \\
- \\
960, \\
000\end{array}$ & $\begin{array}{c}>= \\
75 \%\end{array}$ & $\begin{array}{c}\text { Tidak } \\
\text { Ada }\end{array}$ & 0 \\
\hline 9190 & Agus & aktif & 0 & Bukan & $\begin{array}{l}0- \\
480 \\
000\end{array}$ & $\begin{array}{c}>= \\
75 \%\end{array}$ & $\begin{array}{c}\text { Tidak } \\
\text { Ada }\end{array}$ & 0 \\
\hline 9195 & Frans & aktif & 0 & Bukan & $\begin{array}{l}0- \\
480 \\
000\end{array}$ & $\begin{array}{c}>= \\
75 \%\end{array}$ & $\begin{array}{l}\text { Tidak } \\
\text { Ada }\end{array}$ & 0 \\
\hline 9197 & Mira & aktif & 1 & Bukan & $\begin{array}{l}0- \\
480 \\
000\end{array}$ & $\begin{array}{c}>= \\
75 \%\end{array}$ & Ada & 0 \\
\hline 9198 & Putri & aktif & 1 & Bukan & $\begin{array}{l}480 \\
001 \\
- \\
960, \\
000\end{array}$ & $\begin{array}{c}>= \\
75 \%\end{array}$ & $\begin{array}{c}\text { Tidak } \\
\text { Ada }\end{array}$ & 1 \\
\hline 9203 & Yohan & aktif & 1 & Bukan & $\begin{array}{l}960, \\
001 \\
- \\
1,44 \\
0,00 \\
0\end{array}$ & $\begin{array}{c}>= \\
75 \%\end{array}$ & $\begin{array}{l}\text { Tidak } \\
\text { Ada }\end{array}$ & 0 \\
\hline 9180 & Reyval & aktif & 1 & $\begin{array}{l}\text { Yatim/ } \\
\text { Piatu }\end{array}$ & $\begin{array}{l}0- \\
480 \\
000\end{array}$ & $\begin{array}{c}>= \\
75 \%\end{array}$ & Ada & 0 \\
\hline
\end{tabular}

d. Matriks Keputusan

Tabel 3. Matriks Keputusan

\begin{tabular}{|c|c|c|c|c|c|c|c|}
\hline \multicolumn{10}{|c|}{ Matriks Keputusan } \\
\hline Nama & C1 & C2 & C3 & C4 & C5 & C6 & C7 \\
\hline Aloy & 0,5 & 0 & 0.5 & 0.75 & 1 & 0 & 0 \\
\hline Anto & 0,5 & 0 & 0 & 1 & 1 & 0 & 0 \\
\hline Giga & 0,5 & 0,25 & 0 & 0.5 & 1 & 0 & 1 \\
\hline Skola & 0,5 & 0.5 & 0 & 0.75 & 1 & 0 & 0 \\
\hline Agus & 0,5 & 0 & 0 & 1 & 1 & 0 & 0 \\
\hline Frans & 0,5 & 0 & 0 & 1 & 1 & 0 & 0 \\
\hline Mira & 0,5 & 0,25 & 0 & 1 & 1 & 1 & 0 \\
\hline Putri & 0,5 & 0,25 & 0 & 0.75 & 1 & 0 & 1 \\
\hline Yohan & 0,5 & 0,25 & 0 & 0.5 & 1 & 0 & 0 \\
\hline Reyval & 0,5 & 0,25 & 0.5 & 1 & 1 & 1 & 0 \\
\hline
\end{tabular}

e. Normalisasi Matriks Keputusan

Tabel 4. Normalisasi Matriks Keputusan

\begin{tabular}{|c|c|c|c|c|c|c|c|}
\hline \multicolumn{7}{|c|}{ Normalisasi Matriks Keputusan } & \multirow[b]{2}{*}{ C7 } \\
\hline Nama & C1 & $\mathbf{C 2}$ & C3 & $\mathrm{C4}$ & C5 & C6 & \\
\hline Aloy & $\overrightarrow{\tilde{o}} 0$ & $8_{0}^{8} 0$ & $\frac{R}{0} r$ & $\stackrel{\text { N }}{0}_{0}$ & $\vec{\sigma} 0$ & $\tilde{n}_{0}$ & $\underset{0}{8}$. \\
\hline Anto & $\tilde{0}=$ & ‥ & $\stackrel{\circ}{0}$. & $\tilde{0} \cong$ & $\tilde{n}_{0}=$ & $\tilde{n}_{0}=$ & $\stackrel{\circ}{0} \AA$ \\
\hline Giga & 30 & $\stackrel{m}{0} m$ & $\stackrel{\circ}{\circ} \&$ & $\overrightarrow{0} \hat{\infty}$ & $\mathfrak{m}^{2} 0$ & $\mathfrak{n}^{2}=$ & ڤू ले \\
\hline Skola & $\tilde{0}=$ & $\ddot{0}$ & $\stackrel{0}{0}$. & గn $\infty$ & $\tilde{n}_{0}=$ & $\tilde{o}=$ & $\because \sqrt{0}$ \\
\hline Agus & $\tilde{0}=$ & 요 & O. & $\tilde{0} \pi$ & $\tilde{0}=$ & $\hat{0}=$ & $\because g$ \\
\hline Frans & $\hat{0}=$ & 용 & $\stackrel{\circ}{\circ} \&$ & $\hat{0} \approx$ & $\hat{\sigma}=$ & $\hat{n}=$ & $\stackrel{\circ}{\circ} \mathrm{g}$ \\
\hline Mira & $\hat{0}=$ & $\hat{\sigma} m$ & $\stackrel{\circ}{\circ} \&$ & $\hat{0} \approx$ & $\hat{\sigma}=$ & $\hat{n}=$ & $\hat{0}$ ले \\
\hline Putri & $\tilde{0}=$ & $\hat{\sigma} m$ & $\stackrel{\circ}{0}$ & $\tilde{0} \lesssim$ & $\hat{0}=$ & $\hat{0}=$ & $\hat{0} \mathrm{~d}$ \\
\hline Yohan & 30 & $\stackrel{m}{0} m$ & $\stackrel{\circ}{0} \&$ & $\overrightarrow{0}$ & $\mathfrak{n}^{2} 0$ & $\stackrel{n}{0}=$ & ले ले \\
\hline Reyval & $\tilde{o}=$ & $\tilde{\sigma} m$ & $\hat{0}$ & $\tilde{0} \cong$ & $\hat{n}=$ & $\hat{0}=$ & के ले \\
\hline
\end{tabular}

Langkah 1 Akar dari jumlah tiap cell yang dipangkatkan 2:

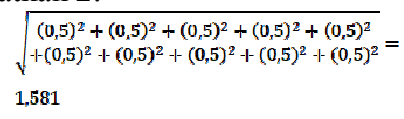

Langkah 2 Membagi nilai cell dengan hasil langkah pertama:

$$
0,5 \div 3,354=0,316
$$


Volume 4, Edisi 2, Februari 2018

f. Matriks Bobot Ternormalisasi

Tabel 5. Matriks Bobot Ternormalisasi

\begin{tabular}{|c|c|c|c|c|c|c|c|}
\hline \multicolumn{7}{|c|}{ Matrik Bobot Ternormalisasi } & \multirow[b]{2}{*}{ C7 } \\
\hline Nama & C1 & $\mathrm{C2}$ & C3 & $\mathrm{C4}$ & C5 & C6 & \\
\hline Aloy & $\tilde{0} \hat{n}$ & $\therefore 8$ & $\tilde{0}$ & 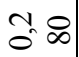 & $\tilde{0}, \tilde{m}$ & $\stackrel{\circ}{0} \cong$ & $\because g$ \\
\hline Anto & $\tilde{0} \hat{n}$ & $\stackrel{0}{0} 8$ & ㅇ. & $\tilde{0} \cong$ & $\tilde{0} \hat{n}$ & $\stackrel{0}{0} \cong$ & $\stackrel{\circ}{\circ} \mathrm{g}$ \\
\hline Giga & $\tilde{0} \hat{n}$ & $\hat{n} m$ & 용 & $\overrightarrow{0}-\infty$ & $\tilde{c}, \bar{n}$ & $\stackrel{\circ}{\circ} \varrho$ & $\tilde{0} \widehat{a}$ \\
\hline Skola & $\tilde{0} \hat{m}$ & $\begin{array}{ll}0 & 0 \\
0 & 6\end{array}$ & ㅇ. 8 & 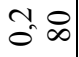 & $\tilde{0} \tilde{m}$ & $\stackrel{\circ}{0} \varrho$ & $\stackrel{\circ}{\circ} \mathrm{g}$ \\
\hline Agus & $\tilde{0} \hat{n}$ & $\stackrel{\circ}{0} 8$ & $\circ 8$ & $\tilde{0} \approx$ & $\tilde{0} \pi$ & $\stackrel{\circ}{\circ} \Xi$ & $\stackrel{\circ}{\circ} \mathrm{g}$ \\
\hline Frans & $\tilde{0} \hat{n}$ & $\stackrel{0}{0} 8$ & ㅇ. 8 & $\tilde{0} \cong$ & $\tilde{o} n$ & $\stackrel{\circ}{0} \S$ & \\
\hline Mira & $\tilde{0} \hat{m}$ & $\hat{\sigma} m$ & ‥ & $\hat{0} \cong$ & กู & $\hat{0} \hat{C}$ & $\stackrel{\circ}{0} \mathrm{~g}$ \\
\hline Putri & $\tilde{0} \hat{n}$ & $\tilde{n} m$ & ㅇ. 8 & 됴 $\infty$ & $\tilde{o} n$ & $\stackrel{0}{0} \S$ & \\
\hline Yohan & $\tilde{0} \hat{n}$ & $\tilde{\sigma} m$ & $\stackrel{\circ}{\circ} 8$ & $\overrightarrow{0} \infty$ & $\tilde{0} \pi$ & $\stackrel{\circ}{\circ} \S$ & $\stackrel{\circ}{\circ} \mathrm{g}$ \\
\hline Reyval & $\hat{\sigma} \hat{m}$ & $\stackrel{m}{0} m$ & $\hat{\sigma} \hat{0}$ & $\hat{0} \cong$ & $\tilde{0} \pi$ & $\tilde{\sigma} \hat{a}$ & \\
\hline
\end{tabular}

g. Faktor Ideal Positif

Tabel 6. Faktor Ideal Positif

\begin{tabular}{|c|c|c|c|c|c|c|c|}
\hline \multicolumn{7}{|c|}{ Faktor Ideal Positif } & \multirow[b]{2}{*}{ C7 } \\
\hline Nama & C1 & $\mathrm{C2}$ & C3 & $\mathrm{C4}$ & C5 & C6 & \\
\hline Aloy & $8_{0}^{\circ} 0$ & $\stackrel{J}{\sigma}_{\sigma}^{+}+$ & $8_{0}^{\circ}$ & $8_{0} a$ & $8_{0} 0$ & $\stackrel{n}{0} 0$ & $\tilde{n}_{0}$ \\
\hline Anto & 0.8 & $\stackrel{\sim}{\circ}_{0} \forall$ & n. 8 & $\circ 8$ & $\because 8$ & $\approx q$ & $\approx q$ \\
\hline Giga & $\stackrel{0}{0} 8$ & $\overrightarrow{0}=$ & no & $O_{0} n$ & $\because 8$ & $\approx \approx$ & $\therefore$. \\
\hline Skola & 0.8 & 0.8 & ñ 8 & 0.8 & 0.8 & $n g$ & $n$ \\
\hline Agus & $\stackrel{0}{0} 8$ & $\dot{\sigma}_{\circ} \forall$ & $n_{0}^{n} 8$ & $\stackrel{0}{0} 8$ & $\stackrel{0}{0} 8$ & $\approx q$ & $n g$ \\
\hline Frans & $\stackrel{0}{0} 8$ & $\dot{\sigma}_{\circ} \forall$ & n.8 & $\stackrel{0}{0} 8$ & $\stackrel{0}{0} 8$ & $\approx q$ & $\approx q$ \\
\hline Mira & $\stackrel{0}{\circ} 8$ & $\overrightarrow{0}=$ & n.8 & $\stackrel{0}{0} 8$ & $\stackrel{0}{0} 8$ & $\stackrel{\circ}{\circ} \varsubsetneqq$ & $\because \approx$ \\
\hline Putri & 0.8 & $\overrightarrow{0}=$ & $0_{0}^{n} 8$ & 0.8 & 0.8 & $\approx q$ & O. \\
\hline Yohan & $\stackrel{0}{0} 8$ & $\overrightarrow{0}=$ & 28 & $\mathscr{0}^{\circ} n$ & $\because 8$ & $\approx q$ & $\because \approx$ \\
\hline Reyval & 0.8 & $\overrightarrow{0}=$ & 0.8 & 0.8 & : 8 & $\stackrel{\circ}{\circ} \S$ & $n \approx$ \\
\hline
\end{tabular}

Kriteria 1: $(0,112-0,112)^{A_{2}}=0$

Kriteria 2: $(0,667-0)^{\Lambda_{2}}=0,444$

Kriteria 3: $(0,707-0)^{\Lambda_{2}}=0,500$

Kriteria 4: $(0,191-0,143)^{\kappa_{2}}=0,002$

Kriteria 5: $(0,114-0,114)^{\iota_{2}}=0$

h. Faktor Ideal Negatif

Tabel 7. Faktor Ideal Negatif

\begin{tabular}{|c|c|c|c|c|c|c|c|}
\hline \multicolumn{7}{|c|}{ Faktor Ideal Negatif } & \multirow[b]{2}{*}{7} \\
\hline Nama & C1 & $\mathrm{C2}$ & C3 & $\mathrm{C4}$ & C5 & C6 & \\
\hline Aloy & $\stackrel{8}{\circ}$. & $\stackrel{8}{\circ} 0$ & $\begin{array}{l}i_{0} \\
\text { no }\end{array}$ & $\stackrel{8}{\circ} a$ & $\stackrel{8}{\circ} 0$ & 8 & $\stackrel{8}{0}$ \\
\hline Anto & $\stackrel{\circ}{\circ} 8$ & $\stackrel{\circ}{\circ} 8$ & $\begin{array}{ll}0 & 8 \\
0 & 8\end{array}$ & $\stackrel{0}{0} m$ & $\stackrel{\circ}{\circ} 8$ & $\stackrel{0}{0}$ & $\stackrel{\circ}{\circ} \S$ \\
\hline Giga & $\because 8$ & $\overrightarrow{0}=$ & O. & 0.8 & O. 8 & $O_{0}^{\circ}$ & $n$ \\
\hline Skola & $\stackrel{\circ}{\circ} 8$ & $\stackrel{+}{0}$ 寸 & $\begin{array}{ll}0 & 8 \\
0 & 0\end{array}$ & $\stackrel{0}{0} 8$ & $\stackrel{\circ}{\circ} 8$ & $\stackrel{0}{0}$ & $\stackrel{0}{0} 9$ \\
\hline Agus & $\stackrel{\circ}{\circ} 8$ & $\stackrel{\circ}{\circ} 8$ & $\stackrel{0}{0} 8$ & $\stackrel{0}{0} m$ & $\circ 8$ & $\stackrel{0}{0}$ & $\stackrel{\circ}{\circ} \notin$ \\
\hline Frans & $\stackrel{0}{0} 8$ & $\stackrel{0}{0} 8$ & $\begin{array}{ll}0 & 8 \\
0 & 8\end{array}$ & $\stackrel{0}{0} m$ & $\stackrel{\circ}{\circ} 8$ & $\stackrel{0}{0}$ & $\stackrel{\circ}{0} \S$ \\
\hline Mira & $\stackrel{0}{0} 8$ & $\overrightarrow{0}=$ & $\stackrel{0}{0} 8$ & $O_{0} m$ & $\circ 8$ & 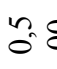 & $\stackrel{\circ}{\circ} 9$ \\
\hline Putri & O. 8 & $\overrightarrow{0}=$ & $\begin{array}{ll}0 & 8 \\
0 & 8\end{array}$ & 0.8 & $\circ 8$ & O. & $\ddot{\circ} \approx$ \\
\hline Yohan & $\stackrel{0}{0} 8$ & $\overrightarrow{0}=$ & $\stackrel{0}{0} 8$ & $\circ .8$ & $\stackrel{0}{0} 8$ & $0_{0}^{\circ}$ & $\circ$ \\
\hline Reyval & $\stackrel{0}{0} 8$ & $\overrightarrow{0}=$ & ñ 8 & $0_{0} n$ & 0.8 & $\tilde{o} \varepsilon$ & 0. \\
\hline $\begin{array}{l}\text { Kriteria } \\
\text { Kriteria } \\
\text { Kriteria } \\
\text { Kriteria }\end{array}$ & $\begin{array}{l}\text { 2: }(0 \\
\text { 3: }(0 \\
4:(0,0\end{array}$ & $\begin{array}{l}12-0 \\
-0)^{\wedge} 2 \\
-0)^{\wedge} 2 \\
95-0,14\end{array}$ & $\begin{aligned} &12)^{\Lambda_{2}} \\
&= 0 \\
&= 0 \\
&3)^{a_{2}}=\end{aligned}$ & & & & \\
\hline Kriter & . & 01 & 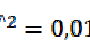 & & & & \\
\hline
\end{tabular}

i. Jarak Solusi Positif dan Negatif

Tabel 8. Jarak Solusi Ideal

\begin{tabular}{|c|c|c|c|}
\hline \multicolumn{4}{|c|}{ Jarak Solusi Ideal } \\
\hline NIS & Nama & D+ & D- \\
\hline 9206 & Aloy & 1,205 & 0,713 \\
\hline 9208 & Anto & 1,394 & 0,187 \\
\hline 9220 & Giga & 1,070 & 0,782 \\
\hline 9216 & Skola & 1,228 & 0,673 \\
\hline 9190 & Agus & 1,394 & 0,187 \\
\hline 9195 & Frans & 1,394 & 0,187 \\
\hline 9197 & Mira & 1,054 & 0,804 \\
\hline 9198 & Putri & 1,058 & 0,787 \\
\hline 9203 & Yohan & 1,283 & 0,333 \\
\hline 9180 & Reyval & 0,782 & 1,070 \\
\hline
\end{tabular}


Jarak Solusi Ideal Positif (D+): $\sqrt{(0+0,444+0,500+0,002+0)}=$

0,973

Jarak Solusi Ideal Negatif (D-): $\sqrt{(0+0+0+0+0,002+0,013)}=$

0,124

j. Nilai Preferensi

Tabel 9. Preferensi dan Perankingan

\begin{tabular}{|c|c|c|c|}
\hline \multicolumn{4}{|c|}{ Preferensi dan Perankingan } \\
\hline NIS & Nama & Preferensi & Rangking \\
\hline 9206 & Aloy & 0,372 & 5 \\
\hline 9208 & Anto & 0,118 & 8 \\
\hline 9220 & Giga & 0,422 & 4 \\
\hline 9216 & Skola & 0,354 & 6 \\
\hline 9190 & Agus & 0,118 & 8 \\
\hline 9195 & Frans & 0,118 & 8 \\
\hline 9197 & Mira & 0,433 & 2 \\
\hline 9198 & Putri & 0,427 & 3 \\
\hline 9203 & Yohan & 0,206 & 7 \\
\hline 9180 & Reyval & 0,578 & 1 \\
\hline
\end{tabular}

\section{Implementasi}

\subsection{Implementasi Antarmuka}

Pada bab ini penulis menampilkan hasil dari rancangan antarmuka yang ada pada bab sebelumnya untuk memperlihatkan bentuk dari sistem setelah sistem itu dituangkan kedalam sebuah media elektronik melalui suatu bahasa pemrograman.

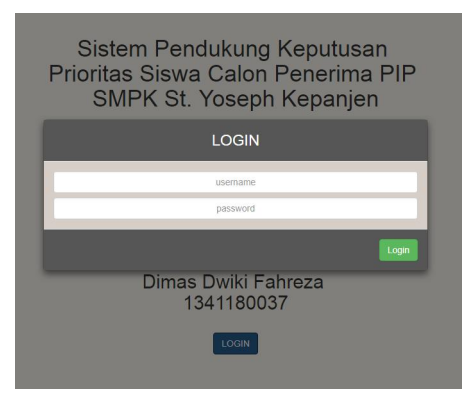

Gambar 6. Halaman Login

Selanjutnya pengguna akan diarahkan menuju tampilan lihat data siswa yang telah disimpan. Pengguna harus memilih tahun angkatan siswa yang tersedia pada dropdown.

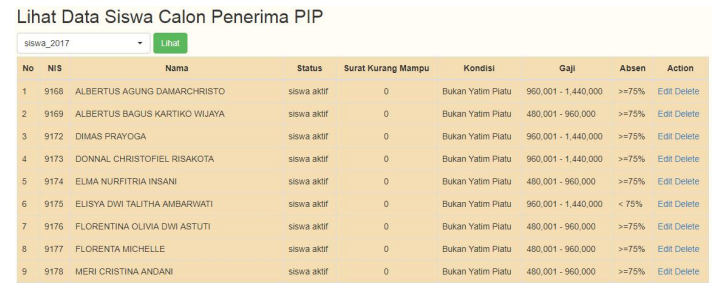

Gambar 7. Halaman Lihat Data
Fitur edit adalah fitur yang dapat digunakan untuk merubah data siswa ketika data tersebut terdapat kesalahan.

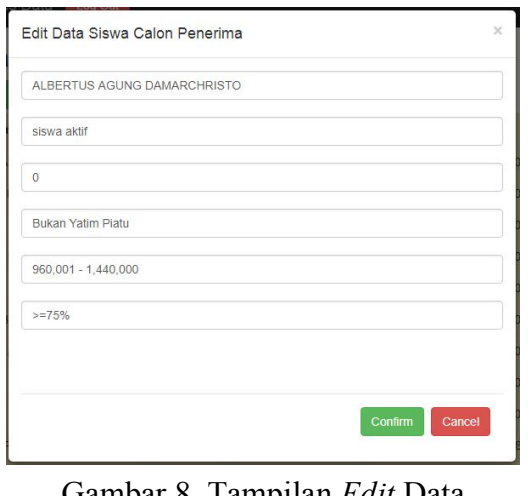

Fitur delete adalah fitur yang digunakan untuk menghapus salah satu data siswa ketika siswa tersebut tidak lagi terdaftar sebagai siswa aktif sekolahan dan pihak sekolah perlu untuk menghapus data tersebut.

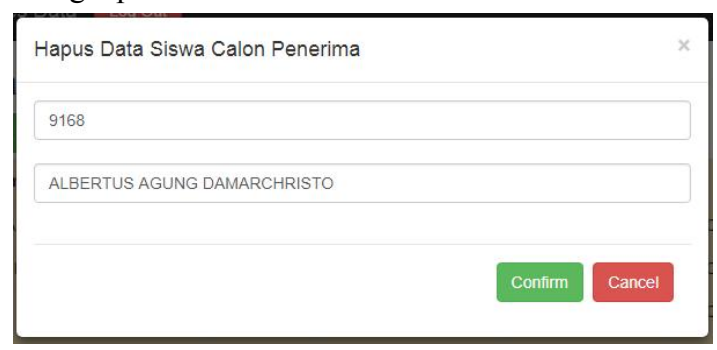

Gambar 9. Tampilan Hapus Data

Pada halaman import data, pengguna melakukan pemindahan data yang berawal dari excel ke basis data $s q l$.

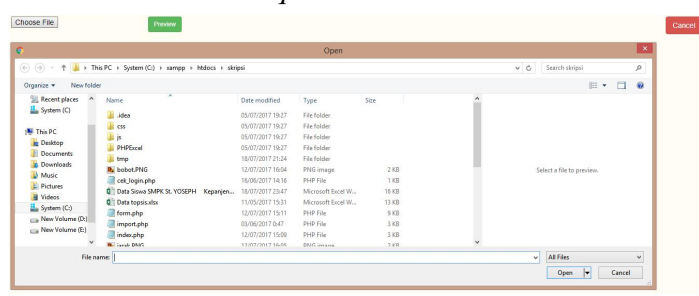

Gambar 10. Tampilan Import Data

Halaman proses data adalah halaman yang menggunakan metode TOPSIS untuk melakukan perhitungan dan perangkingan pada data siswa yang telah tersedia. Pengguna terlebih dahulu memilih tahun siswa yang ingin diproses pada drop down lalu tekan tombol proses untuk menampilkan hasil dari data yang akan dihitung dan perangkingan data menurut nilai preferensi pada $t a b$ terakhir, urutan $t a b$ sesuai dengan urutan proses metode TOPSIS. 


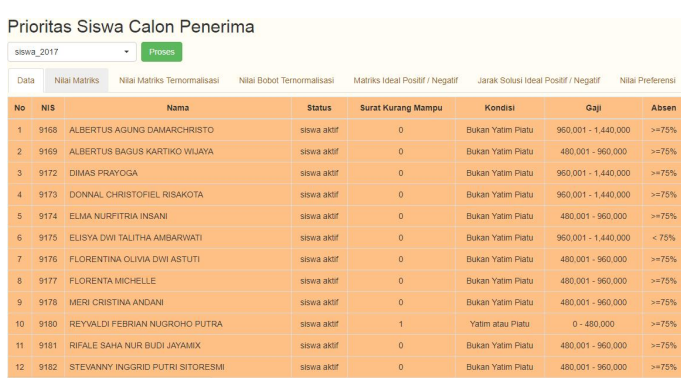

Gambar 11. Halaman Proses Data

Pada bagian akhir proses, peneliti membuat tabel preferensi yang digunakan untuk menyimpan nilai preferensi. Setelah disimpan, nilai akan ditampilkan kembali dan diurutkan dari nilai tertinggi ke nilai terendah.

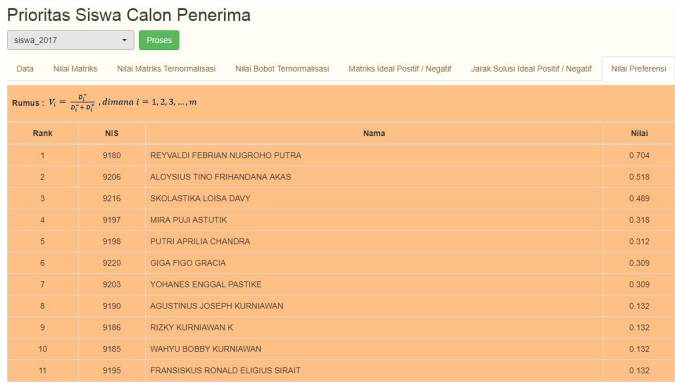

Gambar 12. Tampilan Nilai Preferensi dan Ranking

\section{Kesimpulan dan Saran}

\subsection{Kesimpulan}

Dari penelitian yang dilakukan dan pembahasan bab-bab sebelumnya, maka dapat disimpulkan bahwa:

1. Aplikasi sistem pakar untuk mendiagnosa penyakit AMS adalah suatu aplikasi untuk mendiagnosa penyakit pada pendaki berdasarkan pengetahuan dari pakar.

2. Dengan adanya Sistem Pakar ini, pendaki atau orang yang membutuhkan sebagai referensi tentang penyakit AMS yang dapat mendiagnosa gejala yang dialami mereka tanpa harus menunggu ahli PPGD dibidang mountaineering.

3. Nilai kepercayaan yang dihasilkan dari sistem ini sama dengan hasil perhitungan secara manual dengan menggunakan teori Dempster Shafer sehingga keakuratan hasilnya sudah sesuai dengan perhitungan yang didapat dari uji coba.

\subsection{Saran}

Berdasarkan pengujian sistem pakar yang digunakan untuk mendiagnosa penyakit AMS ini masih banyak kekurangan dan kelemahan, maka saran yang diberikan sebagai berikut :

1. Perlu adanya perbandingan metode dalam implementasi sistem pakar pada kasus yang sama. Perbandingan metode digunakan untuk mendapatkan validasi hasil yang lebih maksimal.

\section{Daftar Pustaka:}

TNP2K, (2016), Program Indonesia Pintar Melalui Kartu Indonesia Pintar [online], Available: http://www.tnp2k.go.id/id/tanyajawab/klaster-i/program-indonesia-pintarmelalui-kartu-indonesia-pintar-kip

Pemerintah Kabupaten Bangil, (2016), Proses Pembuatan SKTM [online], Available: http://bangil.pasuruankab.go.id/pages-31prosedur-pembuatan-sktm.html

Azarine, Yusriyah, (2016), Pengertian Kartu Keluarga Sejahterah [online], Available: http://www.bpjs-

kesehatan.net/2016/04/pengertian-kartu-

kks.html

Kementerian Sosial, (2016), Pedoman Pelaksanaan $P K H$ [online], Available: http://www.portal.pkh.kemsos.go.id/data/files/B UKU\%20PEDOMAN\%20PELAKSANAAN\%2 0PKH\%202016/BUKU\%20PEDOMAN\%20PE LAKSANAAN\%20PKH\%202016.pdf

TNP2K, (2016), Kartu Perlindungan Sosial [online], Available:

http://www.tnp2k.go.id/id/program/kartu perlindungan-sosial/tentang-kartu-perlindungansosial/

TNP2K, (2016), Kartu Indonesia Sehat [online], Available:

http://www.tnp2k.go.id/id/program/programmembangun-keluarga-produktif/kartuindonesia-sehat/

TNP2K, (2016), Tentang Kartu Indonesia Pintar [online], Available: http://www.tnp2k.go.id/id/program/programmembangun-keluarga-produktif/kartuindonesia-pintar

Riadi, Muchlisin, (2013), Definisi Sistem Pendukug Keputusan [online], Available: http://www.kajianpustaka.com/2013/09/sistempendukung-keputusan-spk.html

Zlatko Pavic \& Vedran Novoselac, (2013), Notes on TOPSIS Method [online], Available: http://www.ijres.org/papers/v1-i2/B120512.pdf

Dudung, (2016), Pengertian, Komponen dan Fungsi XAMPP Lengkap Dengan Penjelasan [online], Available: http://www.dosenpendidikan.com/pengertiankomponen-dan-fungsi-xampp-lengkap-denganpenjelasannya

Arief, M.Rudianto, (2011), Pemrograman Web Dinamis Menggunakan Php dan Mysql. Yogyakarta: ANDI.

Widi, Hastomo, (2013), Pengertian dan Kelebihan Apache Server, [Online] Available: http://hastomo.net/php/pengertian-dankelebihan-apache-serv. 